\title{
Unemployment and the European Union, 2000-2017: structural exploration of distant past economic experience and future prosperity
}

\author{
Enn Lun Yong ${ }^{*}$ (1)
}

\section{${ }^{*}$ Correspondence:}

ennlunyong@gmail.com

Department: Mathematics

with Economics Program,

Faculty of Science

and Natural Resources,

Universiti Malaysia Sabah

(UMS), UMS Street,

88400 Kota Kinabalu, Sabah,

Malaysia

\begin{abstract}
Distant past experience of economic performance is hypothesized to govern long-run employment performance across 28 European Union (EU) state members. Economic studies usually include lag structure for causality analysis, such as the Wold causal chain and recursive vector autoregression. The inquiry of this paper is different from the literature for two reasons: first, it intends to explain theoretically and empirically how long an influence of significant economic experience in the distant past on longrun unemployment would last. Second, the focus is on the EU due to the ongoing debate over economic integration and independent economies, of which Brexit is one prominent example. Based on panel data, a diagrammatic theory conveys the meaning of the distant past economic experience and its relationship with long-run unemployment in the EU. Empirical investigations include causality tests and long-lasting economic influences, where a new simple approach toward Cholesky decomposition is also demonstrated. The effect of an unexpected shock to inflation on unemployment can remain literally substantive for up to nearly four decades, while unemployment effects of some trade-related innovations can last even longer. The results are supported using analogical reasoning of macroeconomic behaviors incorporated in the original concept of this research.
\end{abstract}

Keywords: Analogical reasoning, European Union, Future prosperity, Inflation, Past experience, Unemployment

\section{Introduction}

With respect to unemployment and the Economic and Monetary Union (EMU), Snowdon and Vane (2005) compared the European Union (EU) [e.g., Germany, France, and the United Kingdom (UK)], and the United States (US) with the following inquiries:

Although unemployment in the US and UK economies is relatively low at the moment, the average rate of unemployment in the European Union economies is relatively high. How can we explain the considerable unemployment differentials that exist at the moment between the USA and countries such as France and Germany? Do you think that EMU is likely to exacerbate the unemployment problem in Europe? (Snowdon and Vane 2005, p. 161). 
In relation to the questions above, Snowdon and Vane (2005) inquired about economic reasoning and policies of unemployment in the EU in their interview in 1998 with Nobel laureate, James Tobin. The economic laureate did not expect significant improvement from the EMU to the macroeconomic problem. Moreover, Tobin believed that efforts to tackle unemployment were mostly from individual EU countries, signaling that such country-specific macroeconomic policies will be altered, as the countries are governed under EMU. Following this essential dialogue, the current study suggests that individual EU countries are likely to prefer the past experience of their own macroeconomic policies than the group of policies set under the EU and EMU. If this hypothesis is shown to be valid economically and statistically, the implication is a phenomenon similar to Tobin's articulation of certain structural problems that reflect hysteresis, which is a barrier to suppressing unemployment. However, in this paper's inquiry, what does the hysteresis look like and how would statistical data capture it?

Ball's (2009) study is believed to be the leading investigation that explores unemployment in 20 developed countries based on the hysteresis theory. Ball's theoretical view favors the aggregate demand side rather than the aggregate supply side to explain longrun unemployment. Specifically, Ball's theory implies that unemployment is influenced by aggregate demand, whereby the natural rate of unemployment is influenced thereafter through hysteresis channels. This theory is distinguished from the literature that says aggregate demand causes only short-run changes in unemployment, whereas long-run changes in unemployment are due to supply-side events such as labor market frictions (Friedman 1968). In Ball's perspective, the proposition of hysteresis is not intended to disprove recognized economic theories, and the aim is to improve understanding with respect to the underpinning of unemployment behaviors. Hysteresis, generally, means the dependency of a phenomenon on its own history. The current study's first hypothesis is stated generally here in accordance with Blanchard and Summers (1986) and Ball (2009): if the actual rate of unemployment is higher than the natural rate, there exist forces that will pull the natural rate to the actual path, which is a long-run mechanism of hysteresis. However, in contrast to Ball's argument for aggregate demand, this paper tests both supply-side and demand-side effects represented by fiscal, nominal, and traderelated activities. Furthermore, in the second hypothesis, this paper intends to quantify the long-lasting influences from these activities on unemployment.

Following the hypotheses above, the methodology is focused on the pattern of actual unemployment rates, recognizing that the natural rate follows this pattern due to hysteresis. This study's approach is to use data on EU countries, because this allows the hypothesis to be tested for a region aiming at political and economic integration. The implication is significant, because the EU policies need to take into consideration barriers from long run and persistent hysteresis effects. As a matter of fact, economists generally are not confident with the EU policies solidly to bring about political and economic integration, thereby signaling the reason for Brexit. From Alesina et al's (2005) study of country size and growth, the increase of EU member countries is asserted: on the one hand, this magnifies preference heterogeneity, and on the other hand, benefits of country size are downgraded due to economic integration. Specifically, Alesina and colleagues contend that the objective of the EU to achieve economic integration is a matter at the European level, while regional separatism seems to be more apparent in some member states. Taking fully the acquis, communautaire 
of the EU is believed to be a major challenge to those Associated Countries (ACs), because the ACs could face inflationary pressure following the real appreciation of exchange rate during the transition process, where flexibility in the exchange rate regime is required to address inflationary pressure (Daviddi and Ilzkovitz 1997). Daviddi and IIzkovitz assert that the transition period is important to prepare the ACs to participate in the EMU. Some countries have shown remarkable efforts toward macroeconomic stability policies. However, Europe will only be a union of independent countries (Alesina and Perotti 2004). One argument for this position by Alesina and Perotti is that the concept of EU was initiated by a group of established economies which do not share the same secular history, particularly institutions and internecine wars. Thus, this encourages an emphasis on a balanced institution, which subsequently leads to the confusion of power among member countries. Moreover, Alesina and Perotti also postulate a potential clash in establishing a common market structure, because some regions (e.g., Southern Europe) prefer heavy government intervention in market activities, while other regions prefer a largely free market. Moreover, to gain EU membership, the transition countries are required to pursue costly transformation that can cause an upsurge in government expenditures, which could violate the requirement of 3\% upper limit of budget deficit relative to gross domestic product (GDP) (Svejnar 2002). Svejnar asserts that the transition economies learned to adapt their government budget to local factors and mixed advice from western countries, International Monetary Fund, World Bank, and EU; some countries also experienced increases in unemployment rates during the transition (this could be the effect of the countries suppressing inflationary pressure). In particular, the Public Opinion Research Center (1999) reported negative perspectives of many people in the Czech Republic, Hungary, and Poland following political integration, despite that these countries were shown to be the most advanced transition economies in the EU. Dabrowski (2010) pinpoints the weakness of the EU in tackling financial downturn of member countries following the hit of the global financial crisis in 2008. The role as a union is deemed faded as nationalization of fiscal response was used by offering emergency packages to rescue members with financially troubled institutions. This approach generally produces "economic nationalism," which Dabrowski articulates to be multifold: cross-country financial contagion happens at different speeds and strengths, responses of individual economies to financial shock are uneven, uneven rescue capacity and resources, panic reactions at the national level, and free-riding temptation. The postulation above implies the need for more research knowledge with respect to the EU's economic experience. Using panel-data analysis with dynamic and structural specifications, this paper's methodology is based on the EU to obtain important knowledge pertaining to the distant past economic experience and possible long-lasting influences into the future, arguably two hypotheses that have not been explored.

The following section explains the theoretical proposition, to which this paper deploys analogical reasoning in favor of the hysteresis concept.

\section{Theoretical proposition}

\subsection{Past experience and analogical reasoning}

In economic jargon, short run and long run are structural mechanisms underpinning an economic behavior over time, such as changes in unemployment and its relations with the other five fundamentals of economic prosperity in this paper. As an argument, 
drafting long-run macroeconomic policy should give a priority to important past experience, as Snowdon and Vane (2005 p. 468) asserted, "Individuals in the real world must decide whether past experience provides a useful guide to the future." This conjecture implies influences on one's perception of an economic problem before taking an action. For example, a decision in the demand behavior of insurance can be characterized by a cumulative effect of past experience (context); theoretically, one is expected to modify the perception of insurance demand after experiencing (or witnessing) not one but multiple examples of catastrophic losses (Cohen et al. 2008). The outcome of a decision is evaluated by the decision maker using the actual experience of the outcome or consequence as a criterion, emphasizing the importance to recognize the quality of experience realized by the decision maker (Tversky and Kahneman 1991). Following the above explanation, in a macroeconomic context, this paper arguably proposes that the past experience realized by each EU member state represents the main knowledge to address current economic problems to achieve future prosperity. The basis for this proposition is the theory of analogical reasoning, a conceptual strategy of planning and problem solving based mainly on analog past experience (Carbonell 1983). This concept is distinguished from deductive and inductive reasoning; deductive reasoning aims at developing an understanding of a problem by subscribing to principles and theoretical knowledge, whereas inductive reasoning aims at deriving a diagnosis of a problem by scrutinizing facts (Eichengreen 2012). Furthermore, Eichengreen's study of economic history explains that economic policy makers favor particularly the use of analogical reasoning when encountering an economic crisis. As far back as the days of Aristotle, this reasoning approach was recognized for inferring occurrences of geological events at the Devonian age based on the analog occurrence of the current time (Hollander 1916). However, there is also a comment from Hollander that this reasoning, although it often leads scholars to comprehend various phenomena across the world, can only be regarded as a hypothesis.

The theoretical structure of this paper is depicted in Fig. 1. Based on the explanation above, the two hypotheses in the figure scrutinize the extent to which the past experience can stay effective over a long-time period, thereby influencing current macroeconomic behaviors. This is indicated by the flow from labels 1 to 3 , whereby label 2 implies the importance of time that channels the effects of past experience to current behaviors and decisions. Further details are provided below.

\subsection{Hypothesis with respect to time effect: distance and span}

The theoretical idea (Fig. 1) is inspired by Gabor (1989) with respect to the economic reforms amid the "first economy" and "second economy" in Hungary. The second economy was popularized in the 1960s following substantial improvement in living standards. However, changes in attitude toward this economic structure were apparent in the late 1970s; over time, as new problems were recognized, more consistent policies were introduced. Nevertheless, the raison d'être of the second economy remains intact, particularly to supplement the first economy in terms of living standards. The consequence of this is marked by the preference for wage differentials that could make job performance and labor turnover worse off. Harmonizing the two economic structures seems to be the priority to achieve future prosperity 


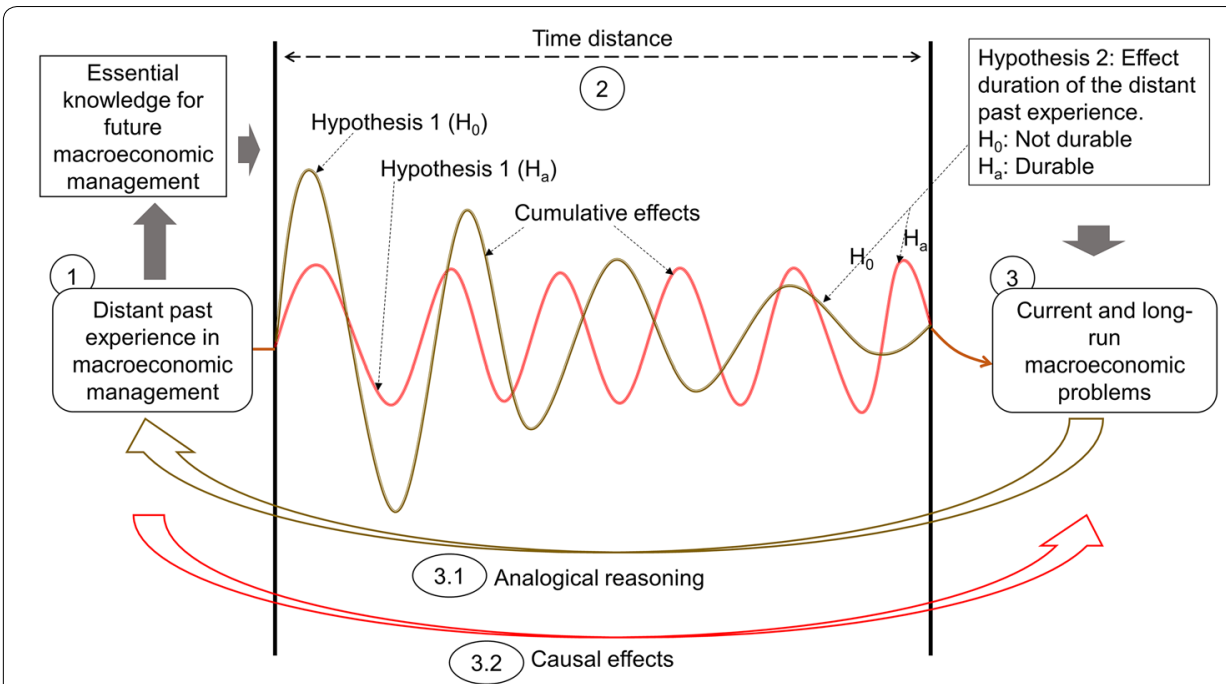

Fig. 1 Economic experience in the distant past and long-run unemployment. The theoretical design is an original work of this paper

in Hungary. From this historical illustration, the current paper learns that the rise of the second economy is a complement to the first, although significant problems and reforms have been recognized, the desire to improve the second economy persists for a long-time period, suggesting that Hungary's future economic prosperity is influenced by the cumulative effect of its past experience. However, the current study also believes that such dependency is subject to the period involved, whether the past experience is only a short-time occurrence or long-time phenomenon. In Fig. 1, the future-past dependency in the long run is shown by the stability of waves, denoted to be the alternative hypothesis $\left(\mathrm{H}_{\mathrm{a}}\right.$ of hypothesis 1$)$. The null hypothesis ( $\mathrm{H}_{0}$ of hypothesis 1$)$ is that the future-past dependency is not significant as the cumulative effect will vanish and will not sustain over a considerable length of time, where future economic performance is only dependent on more recent experience rather than on the distant past. This suggests two null hypotheses: (1) a distant past experience has no causal effect on long-run unemployment and (2) the cumulative effect of a distant past experience is not durable. From economic studies of civilian traits, economic effects due to time separation were ascertained by Spolaore and Wacziarg $(2009,2013,2016)$, as division of human traits can happen over a long period of time, implying that barriers for populations developed with distinct cognitive ability and traits to equalize economic development and harmonize social relations. This work has an essential implication for the current study, because time distance in this paper could imply new or different generations in the labor force, business, and governmental body. Consequently, important past experience might not show any contribution to current economic performance, as illustrated by the two null hypotheses in the figure.

By plotting the EU data on inflation and unemployment from 2000 until 2017, the following illustrations visually trace out the pattern of distant past experience and the implication of analog experience. 


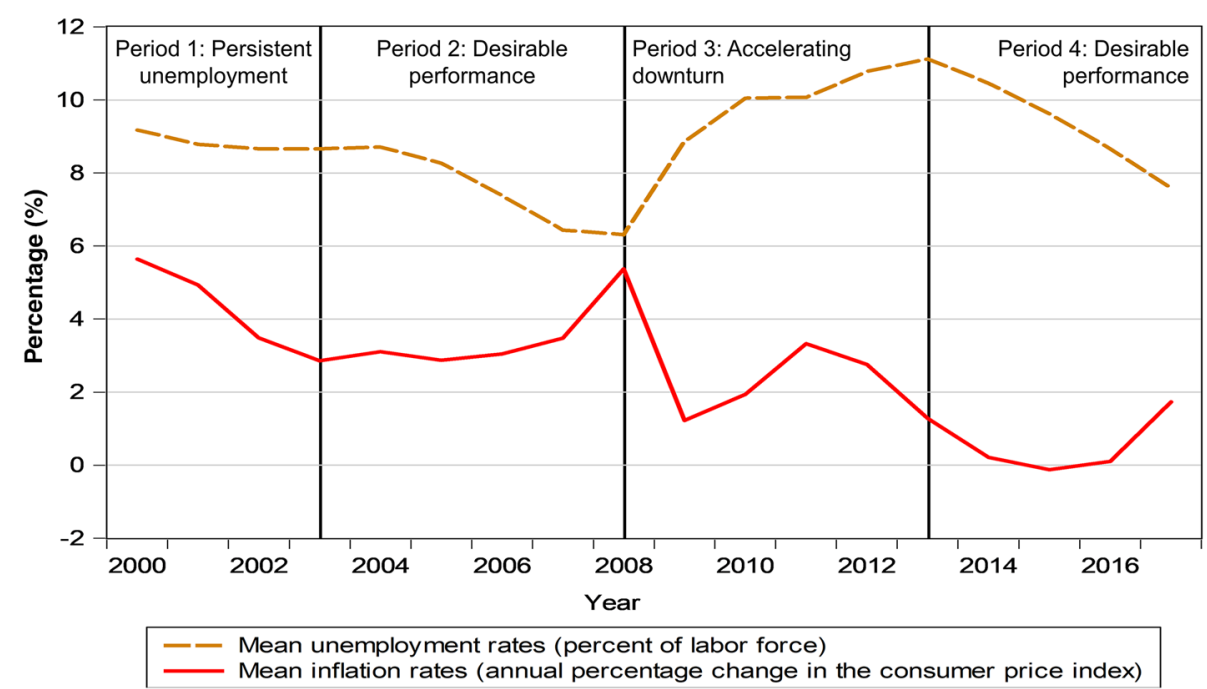

Fig. 2 Inflation and unemployment rates, 2000-2017. The inflation and unemployment data on the 28 EU countries are sourced from the World Development Indicators database (2019) of the World Bank

\subsection{Empirical illustrations with the European Union}

Figure 2 presents the relation between inflation and unemployment averaged over the 28 EU economies. Fisher's $(1926,1973)$ initial investigation of the inflation-unemployment relationship is consistent with the realization of the Phillips curve. ${ }^{1}$ Fisher ascertained the causal effect from inflation to unemployment with the explanation that inflation provides incentives for the population to pursue profitable businesses, therefore, reducing the unemployment rate. However, Fisher's explanation is a short-run causal relationship with up to 6-month structural lags, after which the causal effect on unemployment is asserted to deplete quickly. According to Fisher, one important source to find causality is that there must be cumulative changes in the causing variable in a consistent direction over a period of time. Accordingly, the current study's two hypotheses extend this source of causality over a very long period, an unknown period that is set out to be identified empirically. There are important reasons to examine long-run economic behaviors according to Baumol (1986). One is that long-run economic studies lead to the understanding of economic convergence. Second, long-run economic data represent the flow of consecutive short-run changes in economic behaviors.

As shown in Fig. 2, the initial realization of an adverse relation between inflation and unemployment by Fisher $(1926,1973)$ can be observed using recent data, demonstrated by the convergence of mean unemployment and inflation rates prior to the global financial crisis in 2008. A closer scrutiny allows the current study to divide the graph into four periods. In the first period (2000-2003), it reveals that inflation was decreasing from 2000 to 2003, whereby unemployment rates remained at around $8.7 \%$, reflecting the sustainability of macroeconomic management to ward off a further increase in the unemployment. Unemployment decreased more

${ }^{1}$ Fisher (1973) is a reprint to accredit Fisher's (1926) first investigation and discovery of the inflation-unemployment relationship in its entirety. 


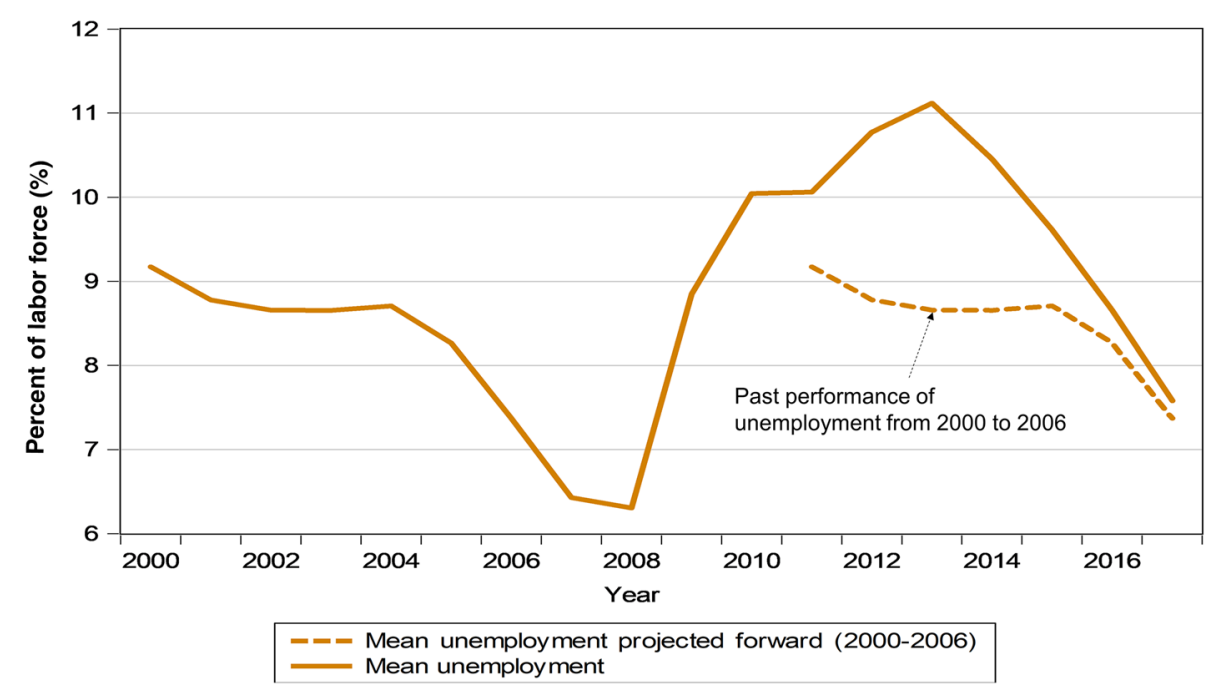

Fig. 3 Analogy of unemployment experience identified from two distant periods. The unemployment data on the 28 EU countries are sourced from the World Development Indicators database (2019) of the World Bank

aggressively as inflation rose from 2004 until 2008 (in the second period); a period of substantial improvement to employment performance with a slowdown in 2007. Entering the third period, the 2007-2008 financial crisis reversed the reduction of unemployment until 2013, while the inflation rate fell to $1.2 \%$ and remained low for the rest of the third period. This pattern is still consistent with Fisher's observation, where inflation and unemployment remained adversely related. However, the fourth period seems to show a unique and unrecognized relation in the sense that while inflation became undesirably low, unemployment showed a persistent decrease. This raises a curiosity with respect to the factor that caused the fall of unemployment, which is unlikely to be inflation. First, the rebound of inflation rates over the fourth period was still too low to revitalize employment performance, which was below $2 \%$ on average. Second, the substantial fall of price level, since the crisis apparently led to the rise of unemployment in the third period, the further decrease of price level when entering the fourth period is not likely to contribute to employment. One possibility is the two hypotheses of distant past performance realized from 2000 until 2006. Looking back from 2017 to 2006, this is equivalent to a lag of 11 years in the jargon of Granger causality.

Figure 3 shows some analogies of unemployment experiences between 2000-2006 and 2013-2017. The short dash line in the figure represents the past experience of unemployment realized in 2000-2006, which is projected forward. Is it this past performance that helped to lower unemployment over the 2013-2017 period? If this speculation is true, this paper's interpretation is that there is the notion of analogical reasoning, where the EU countries recognize the importance of economic knowledge realized in the distant past to manage a current unemployment crisis. 
Table 1 Variables and data

\begin{tabular}{|c|c|}
\hline Category & Economic indicators \\
\hline Fiscal, F & $\begin{array}{l}\text { Fiscal generally means government expenditures and revenues. This paper aims to capture the } \\
\text { economic contribution between public debt and investment subsidy (e.g., Saint-Paul 1992). } \\
\text { This has the implication of fiscal policy on long-run growth (e.g., Barro and Sala-I-Martin } \\
\text { 1992). Thus, the fiscal effect is based on the performance of real GDP. This variable is meas- } \\
\text { ured using the log of constant } 2010 \text { US dollars. The data are sourced from the World Bank } \\
\text { national accounts data (2019) }\end{array}$ \\
\hline Nominal, $N$ & $\begin{array}{l}\text { According to Fisher }(1926,1973) \text {, inflation should be measured using changes in consumer } \\
\text { price. This is indicated by annual inflation rates that capture percentage changes in the cost } \\
\text { of a basket of goods and services for an average consumer. The data are sourced from the } \\
\text { International Financial Statistics and data files (2019) of the International Monetary Fund }\end{array}$ \\
\hline Trade-related, $R$ & $\begin{array}{l}\text { Trade-related effects are tested using three variables. In addition to a trade variable, larger } \\
\text { country size can enhance gains from trade (Alesina et al. 2005). Therefore, the size of the labor } \\
\text { force is also used as a trade-related variable. Recognizing that the elasticity of labor-capital } \\
\text { substitution can determine how unemployment can be influenced by labor supply and } \\
\text { capital investment (Rowthorn 1999), this paper includes capital as the other trade-related } \\
\text { variable, where trade is measured in percent of GDP, labor force is measured using the log } \\
\text { of total people of age } 15 \text { years and older, and gross capital formation is measured using the } \\
\text { log of constant } 2010 \text { US dollars. The data on labor supply were derived by the World Bank } \\
\text { using the data from the ILOSTAT database (2019) of the International Labour Organization. } \\
\text { The data on capital formation and trade are sourced from the World Bank national accounts } \\
\text { data (2019) }\end{array}$ \\
\hline Dependent, $U$ & $\begin{array}{l}\text { Unemployment is chosen as a dependent variable, not only because high employment is } \\
\text { one of the major goals of economic policy (Friedman 1968; Snowdon and Vane 2005, p. 7), } \\
\text { unemployment is shown to cause depression worse than inflation in a study of } 12 \text { European } \\
\text { countries and the US (Di Tella et al. 2001). Unemployment is measured in percent of the total } \\
\text { labor force; the data are estimates provided by the International Labor Organization and have } \\
\text { been harmonized for cross-country comparability over time in terms of scope of coverage, } \\
\text { methodology, data sources, and other country-specific factors. The data are sourced from the } \\
\text { ILOSTAT database (2019) of the International Labour Organization }\end{array}$ \\
\hline
\end{tabular}

The compilation of the indicators stated in this table is available from the World Development Indicators database (2019) of the World Bank

\section{Estimation methods}

\subsection{Data}

From the theoretical proposition in the previous section, a methodology is set out to capture the effect of economic experience in the distant past on long-run unemployment. Referring to Andrés et al. (1996), the current study considers three categories of macroeconomic variables: fiscal, nominal, and trade-related (Table 1).

\subsection{Data structure and unit-root process}

The analysis begins with unit-root tests to determine the order of integration of each indicator. For this EU case study, a panel data set is specified. The data structure is dimensioned by the 2000-2017 period and 28 cross-sectional units (for the $28 \mathrm{EU}$ countries). The panel unit-root test proposed by Levin et al. (2002) is used to test the null hypothesis that an indicator follows a common unit-root process while controlling for individual effects. The purpose is to ensure no spurious inferences as to the result of nonstationary data, in accordance with the econometric explanation of nonstationary panel-data analysis by Phillips and Moon (2000).

\subsection{Fixed effects}

Determining fixed effects are the next priority. Using the variables specified in Table 1 , the baseline two-way fixed effects model is specified, as in the following equation: 


$$
U_{i t}=\alpha_{i t}+\beta_{1} \log F_{i t}+\beta_{2} N_{i t}+\beta_{3} R 1_{i t}+\beta_{4} \log R 2_{i t}+\beta_{5} \log R 3_{i t}+\mu_{i t},
$$

where subscript $i$ denotes country $(i=1,2, \ldots, 28), t$ denotes year $(t=2000,2001, \ldots$, 2017), the dependent variable, $U_{i t}$ is unemployment rate, $\log F_{i t}$ is the natural $\log$ of real GDP in constant 2010 US dollar, $N_{i t}$ denotes inflation rate, $R 1_{i t}$ indicates trade rate, $\log R 2_{i t}$ is the natural $\log$ of total labor force of age 15 years and above, and $\log R 3_{i t}$ is the natural log of capital formation in constant 2010 US dollar. Further details of the variables and data are presented in Table 1 . The baseline model is estimated by assuming two possibilities, random effects, and two-way fixed effects. In the case that the random-effect specification is valid statistically, there would be a composite error term $\left(\varepsilon_{i t}\right)$, where $\varepsilon_{i t}$ consists of two components, namely, the individual-specific error component $\left(v_{i}\right)$ and the combined cross section and time-series component $\left(\mu_{i t}\right)$, where $\alpha_{i}$ is equal to $\alpha+v_{i}$. Hausman's (1978) correlated random-effect test is used to determine the null hypothesis that there is no misspecification with random effects. In the case that the random-effect specification is invalid statistically, the other possible specification is expected to be a two-way fixed effects model. Therefore, tests for redundant cross section fixed and period fixed effects are then used to verify individual-specific effects and time-specific effects (e.g., Baltagi 2005).

\subsection{Validity of lag structure}

Reduced-form vector autoregression (VAR) can specifically estimate minimum lag structure by computing the Akaike information criterion (AIC), Schwarz information criterion (SIC), and other information criteria, which is the preliminary step to perform impulse-response estimation (Ivanov and Kilian 2005). Because the current study has expected theoretically a minimum of 11 lags (as described in the previous section with Figs. 2 and 3), the statistical validity of this theoretical expectation is checked using AIC and SIC. Statistically, sufficient lag structure in a panel-data VAR is important to ensure that the error term is of white noise (Holtz-Eakin et al. 1988).

\subsection{Dynamic causality and impulse response}

The Granger-causality test (Granger 1969) is used to test hypothesis 1 (Fig. 1), while Cholesky decomposition is used to examine hypothesis 2. The use of the Granger-causality test is justified by Diebold's (2001) articulation that one variable can have a causal effect on another variable if the former has useful information of the latter, "over and above the past histories of the other variables in the system." This statistical definition is virtually equivalent to the causal effect of distant past experience of one economic variable in the sextuple system in this paper. The dynamic system of panel VAR with fixed effects and trend is written according to the demonstration by Abrigo and Love (2016):

$$
\mathrm{Y}_{i t}=\mathrm{Y}_{i t-1} \mathrm{~A}_{1}+\mathrm{Y}_{i t-2} \mathrm{~A}_{2}+\cdots+\mathrm{Y}_{i t-p+1} \mathrm{~A}_{p-1}+\mathrm{Y}_{i t-p} \mathrm{~A}_{p}+\mathrm{X}_{i t} \mathrm{~B}+\mathrm{u}_{i}+\mathrm{e}_{i t},
$$

where $\mathbf{Y}_{i t}$ is a vector of dependent variables and $\mathbf{X}_{i t}$ is a vector of exogenous variables. The vector $\mathbf{u}_{i}$ denotes the fixed effects and the vector $\mathbf{e}_{i t}$ denotes idiosyncratic errors. Vectors $\mathbf{Y}_{i t}, \mathbf{u}_{i}$, and $\mathbf{e}_{i t}$ have the same $1 \times k$ dimension. The vector $\mathbf{X}_{i t}$ has $1 \times l$ dimension. The matrix $\mathbf{A}$ has $k \times k$ dimension and matrix $\mathbf{B}$ has $l \times k$ dimension; both denote a matrix of parameters. 
Controlling for fixed effects in Eq. 2 is subject to evidence identified from estimating the baseline regression results for Eq. 1. The lag structure is hypothesized to be 11 years (as explained in the theoretical proposition); this lag specification is then validated using AIC computed from the VAR model. The selected lag structure should also produce white-noise errors. One limitation of reduced-form VAR is that the error terms are correlated across equations, making it impossible to determine the unique one-period shock for each equation. A typical way to tackle this limitation is to estimate a recursive VAR or structural VAR (Stock and Watson 2001). Based on Stock and Watson's explanation, however, the algorithm of recursive VAR is equivalent to the Cholesky decomposition or factorization of reduced-form VAR. Thus, this decomposition method (with adjustment to the degree of freedom) is applied to perform impulse-response analysis. This paper also suggests a simple technique to determine the Cholesky ordering in the following section, because it is based on VAR and causality results. The impulse response using the Cholesky method is performed to find an answer for hypothesis 2 (Fig. 1).

\section{Results and discussion}

\subsection{Panel unit-root test results}

Nonstationary time series can cause improper statistical inferences according to Durlauf and Phillips (1988); hence, the integrated process of each indicator must be determined in advance. In particular, Durlauf and Phillips's study indicates that nonstationary regression could cause nonnormally distributed coefficient estimates. In addition, in the case of panel data, another concern in this paper is the size difference between the cross section and time series. In particular, an econometric study has shown that when the time-series dimension is lower than 50 observations, the performance of the panel unit-root test can be substantially altered by the size of the cross-sectional dimension (Hlouskova and Wagner 2006). Hlouskova and Wagner's study pinpoints two statistics (out of seven panel unit-root tests under their investigation) that received the smallest size distortions, identified from different combinations of cross section and time series, namely, the unit-root tests by Levin et al. (2002) and Breitung (2000). Furthermore, another essential finding by Hlouskova and Wagner is that these statistics produce the highest power of the test in the case when an intercept is included with or without a linear trend. Accordingly, the results generated using Levin et al's (2002) panel unit-root test are shown in Table 2, testing the null hypothesis of no common unit root. Overall, virtually, all tests reject the null hypothesis, except for one mixed result for international trade due to the linear trend (trend stationary). A stationary time series is necessary for the panel-data regressions to ward off spurious inferences.

\subsection{Baseline regression: potential regional independence}

Modeling fixed effects is one important step in panel-data regressions. For instance, a dynamic regression can produce inconsistent estimates if fixed effects are estimated when the time series is fixed, while the cross section tends to infinity (Nickell 1981). According to this paper's theoretical discussion with Dabrowski's (2010) observation on the EU, unobserved individual-specific effects are expected and could be correlated with the errors. The fixed effects are tested based on the contemporaneous model (Eq. 1) using three methods, namely, the correlated random-effect test (Hausman 1978), 
Table 2 Panel unit-root tests

\begin{tabular}{|c|c|c|c|}
\hline \multirow[t]{2}{*}{ Data form } & \multirow[t]{2}{*}{ Variable } & \multicolumn{2}{|c|}{ Common unit root (Levin et al. 2002) } \\
\hline & & $\begin{array}{l}\text { Individual intercepts } \\
\text { (exogenous variable) }\end{array}$ & $\begin{array}{l}\text { Individual intercepts } \\
\text { and trends (exogenous } \\
\text { variables) }\end{array}$ \\
\hline Level & Capital, log & $-4.321[0.000]^{* * *}$ & $-4.150[0.000]^{* * *}$ \\
\hline Level & Inflation, \% & $-12.849[0.000]^{* * *}$ & $-9.908[0.000]^{* * *}$ \\
\hline Level & Labor, log & $-5.702[0.000]^{* * *}$ & $-4.616[0.000]^{* * *}$ \\
\hline Level & Real GDP, log & $-2.215[0.013]^{* *}$ & $-3.807[0.000]^{* * *}$ \\
\hline Level & Unemployment, \% & $-5.339[0.000]^{* * *}$ & $-2.781[0.003]^{* * *}$ \\
\hline Level & Trade, $\%$ & $-0.808[0.210]$ & $-3.275[0.001]^{* * *}$ \\
\hline
\end{tabular}

***,**, and * denote significance at the $1 \%, 5 \%$, and $10 \%$ levels, respectively. Values in square brackets are probability values. Lag lengths of each unit-root test determined by AIC and SIC are similar. The null hypothesis is a unit root against the alternative of no unit root. All results are calculated using EViews (version 8) panel unit-root tests

Table 3 Fixed-effect versus random-effect regression results (the dependent variable is the natural log of unemployment)

\begin{tabular}{lll}
\hline & $\begin{array}{l}(\mathbf{1}) \\
\text { Random effects }\end{array}$ & $\begin{array}{l}\text { (2) } \\
\text { Fixed effects }^{\mathbf{b}}\end{array}$ \\
\hline Regressors & & \\
Inflation, \% & $-0.163(0.033)^{* * *}$ & $-0.260(0.037)^{* * *}$ \\
Capital, log & $-12.196(0.686)^{* * *}$ & $-8.306(0.901)^{* * *}$ \\
Labor, log & $8.588(0.830)^{* * *}$ & $17.344(1.912)^{* * *}$ \\
Real GDP, log & $4.787(1.068)^{* * *}$ & $-9.605(2.153)^{* * *}$ \\
Trade, \% & $0.009(0.005)^{*}$ & $0.001(0.007)$ \\
Intercept & $52.351(8.695)^{* * *}$ & $199.996(49.658)^{* * *}$ \\
Observations & 504 & 504 \\
R-squared & 0.518 & 0.830 \\
Correlated random-effect test & $78.700[0.000]^{* * *}$ & $661.889[0.000]^{* * *}$ \\
Redundant cross-section fixed-effect test & & $84.590[0.000]^{* * *}$ \\
Redundant period fixed-effect test & & \\
\hline a Random cross-sectional effects are estimated & & \\
b Two-way fixed effects are estimated. ${ }^{* * * * *},{ }^{* *}$, and ${ }^{*}$ denote significance at the $1 \%, 5 \%$, and 10\% levels, respectively. Values \\
in parentheses are standard errors. Values in square brackets are probability values. All results are calculated using EViews \\
(version 8) panel-data regressions
\end{tabular}

redundant cross-sectional fixed-effect test, and redundant period fixed-effect test (based on the examples demonstrated by Baltagi (2005)). The correlated random-effect test rejects the null hypothesis of no misspecification, suggesting inappropriate randomeffect specification (column 1 in Table 3). In the fixed-effect regression (column 2 in Table 3), both cross section and period fixed effects are found to be significant, where the null hypothesis of no fixed effects in each test is rejected.

The contemporaneous regression results also correspond to macroeconomic and international economic interpretations. First, unemployment is dependent negatively on inflation, which is a phenomenon described initially by Fisher $(1926,1973)$ and subsequently the Phillips curve (Phillips 1958). The insignificant dependency on contemporaneous trade suggests that the effect of trade is channeled through capital-labor substitution for international trade. The opposite coefficient signs for the labor force 
and capital investment can suggest the substitution of inputs. According to Freeman and Medoff's (1982) articulation, the ease of capital-labor substitution implies the elasticity of demand for labor, which eventually reflects the economic power of the European Trade Union Confederation. The negative effect of capital investment reflects the displacement of labor for capital inputs, and hence, the growth of the labor force will only cause higher unemployment rates. Last but not least, unemployment depends negatively on real growth. After controlling for capital, labor, and fixed effects, such significant contribution of real growth is attributed to the net effect of fiscal policy in an endogenous growth model with constant returns to capital, namely, investment subsidy that is Pareto-improving outweighs public debt that is not Pareto-improving (e.g., Saint-Paul 1992).

The significant fixed effects from the panel-data regression are more properly regarded as efforts from independent member states than as EU policy performance, which supports the notion of regional separatism (Snowdon and Vane 2005, pp. 564-565). This interpretation is distinguished from the institutional separation hypothesis explained and tested by Kollias and Paleologou (2006) for $15 \mathrm{EU}$ member states, where the null hypothesis of institutional separation is proved as insignificant causality effects (of any direction) between government expenditures and revenues. As evidence that favors the current study's interpretation, Bulgaria has experienced a huge decrease in the unemployment rate since 2001, but became an EU member only in 2007. Croatia also experienced such prosperity, but only became an EU member in 2013. These cases signify individual country efforts, whether or not there was a motivation to be part of the EU. Stronger evidence of regional separatism is shown in the following causality results.

\subsection{Past experience, future prosperity, and regional independence}

A dynamic model with 11 lagged years seems overwhelming in a reduced-form VAR model. This lag structure is justified with three reasons. First, this study believes in the strength of analogical reasoning for economic behaviors. Second, this study recognizes the long run to be a period that enhances understanding of important past experience. Third, this study argues that economies will refer to important past experience, as these countries are hit by significant economic downturn or crisis. Given these reasons, dynamic causality with said lags is estimated, as presented in Table 4. All five economic variables are found to Granger cause long-run unemployment significantly. Recall that the five economic pillars (inflation, real GDP, trade, capital, and labor) represent three fundamentals of economic prosperity, namely, fiscal, nominal, and trade-related dimensions of experience. The important past experience subsumed in these economic-growth pillars, specifically from 2000 to 2006 , is found to be statistically significant on long-run unemployment, shown particularly during the 2013-2017 period, where employment performance improved sharply not long after the downturn period of the global financial crisis. The substantial improvement of the unemployment problem in the 2000-2006 period has been shown to be dependent on the five economic pillars, where such previous dependency is proved to have produced causal effects on long-run unemployment. As shown in Fig. 3, analogical reasoning in the decrease of unemployment is shown 
Table 4 Granger-causality test results

\begin{tabular}{|c|c|c|c|c|}
\hline \multicolumn{5}{|c|}{ Panel A (dependent: unemployment) } \\
\hline Inflation & Real GDP & Trade & Capital & Labor \\
\hline $22.230[0.023]^{* *}$ & $38.164[0.000]^{* * *}$ & $34.603[0.000]^{* * *}$ & $17.564[0.092]^{*}$ & $21.845[0.026]^{* *}$ \\
\hline \multicolumn{5}{|c|}{ Panel B (dependent: inflation) } \\
\hline Unemployment & Real GDP & Trade & Capital & Labor \\
\hline $15.842[0.147]$ & $19.277[0.056]^{*}$ & $10.311[0.503]$ & $13.136[0.285]$ & $22.593[0.020]^{* *}$ \\
\hline \multicolumn{5}{|c|}{ Panel C (dependent: real GDP) } \\
\hline Unemployment & Inflation & Trade & Capital & Labor \\
\hline $24.276[0.012]^{* *}$ & $24.342[0.011]^{* *}$ & $60.274[0.000]^{* * *}$ & $12.714[0.312]$ & $21.058[0.033]^{* *}$ \\
\hline \multicolumn{5}{|c|}{ Panel D (dependent: trade) } \\
\hline Unemployment & Inflation & Real GDP & Capital & Labor \\
\hline $5.248[0.919]$ & $14.485[0.207]$ & $26.484[0.006]^{* * *}$ & $28.153[0.003]^{* * *}$ & $16.802[0.114]$ \\
\hline \multicolumn{5}{|c|}{ Panel E (dependent: capital) } \\
\hline Unemployment & Inflation & Real GDP & Trade & Labor \\
\hline $18.099[0.079]^{*}$ & $39.735[0.000]^{* * *}$ & $92.607[0.000]^{* * *}$ & $14.027[0.232]$ & $21.486[0.029]^{* *}$ \\
\hline \multicolumn{5}{|c|}{ Panel F (dependent: labor) } \\
\hline Unemployment & Inflation & Real GDP & Trade & Capital \\
\hline $11.796[0.379]$ & $9.428[0.583]$ & $9.635[0.563]$ & $10.925[0.450]$ & $8.329[0.684]$ \\
\hline
\end{tabular}

Table 5 Ranking of weak exogeneity

\begin{tabular}{llll}
\hline $\begin{array}{l}\text { Ranking of weakly } \\
\text { exogenous variable }\end{array}$ & $\begin{array}{l}\text { Number of (Granger) } \\
\text { causality on other } \\
\text { variables }\end{array}$ & $\begin{array}{l}\text { Number of feedback } \\
\text { causality with other } \\
\text { variables }\end{array}$ & $\begin{array}{l}\text { Number of weak } \\
\text { exogeneity with other } \\
\text { variables }\end{array}$ \\
\hline 1st: labor & 4 & 0 & 4 \\
2nd: inflation & 3 & 1 & 3 \\
3rd: real GDP & 4 & 3 & 1 \\
3rd: trade & 2 & 1 & 1 \\
4th: unemployment & 2 & 2 & 0 \\
4th: capital & 1 & 1 & 0 \\
\hline
\end{tabular}

between the two separate periods (2000-2006 and 2013-2017), suggesting that these EU economies had successfully used a similar approach from the 2000-2006 period to tackle unemployment during the 2013-2017 period. The dynamic causality results reveal even stronger evidence of regional separatism, because the lag effects of the past economic experience happened in the 13 (out of 28) countries, whose economies were not EU member states during that time.

Other important findings are the ranking of exogeneity. Exogeneity can be distinguished to be weak, strong, or super level; in particular, Granger causality is necessary for strong exogeneity (Gujarati 2003, p. 696). For instance, weak exogeneity with respect to unemployment are identified to be inflation, trade, and labor, because there are no feedback causal effects from unemployment on each of these variables. Based on the 
causality results in Table 4, a ranking of exogeneity (weakly exogenous only) in the sextuple system is identified (Table 5 ). ${ }^{2}$

\subsection{The saga of distant past experience: the further tendency of regional independence}

Modeling structural innovations using Cholesky decomposition is sensitive to the ordering of variables in the sextuple system. In Burbidge and Harrison's (1984) estimation approach of the impulse response, variables are ordered in terms of the most desirable. Accordingly, this paper's most desirable effect is inflation. Nevertheless, based on the exogeneity ranking in Table 5, it seems more subtle to order inflation as the second. Inflation was also arranged to be among the least endogenous in the Cholesky ordering in a VAR modeling with respect to monetary policy (Neuenkirch 2013). The Cholesky ordering in the current study (as shown in Table 5) is justified as follows. Labor supply is determined by the real wage rate (Lucas and Rapping 1969) and the size of the population. Therefore, labor is ordered at the top of the exogeneity list. Because the labor variable is measured as a share of the population (age 15 years and above), its causal effect on inflation can be interpreted according to the New-Keynesian Phillips Curve, "If the underlying market structures and technology have not changed, then high labor shares reflect lower-than-desired markups and thus trigger inflation." Lawless and Whelan (2011 p. 122). The causal effect of inflation on GDP in 14 European countries was quantified by Koulakiotis et al. (2012). A relatively new explanation is that the negative effect of inflation on real GDP growth can be worsened as institutional quality increases (Ibarra and Trupkin 2016); this seems to be typical of the inflation-real growth situation across the $28 \mathrm{EU}$ member states. Real GDP indicates that the values of all goods and services produced after adjusting for inflation in a year, from which the international trade pattern is greatly influenced, because trade performance requires efficient infrastructure. For example, efficient infrastructure for trade, particularly port efficiency (Clark et al. 2004), is found to be dependent on real GDP in South Africa (Perkins et al. 2005). Other than ports for cargo, Perkins and colleagues also found other aspects, including railway lines, locomotives, coaching stock, good stock, passenger journeys, goods vehicles, South Africa Airways passengers, fixed phone lines, and electricity supply. The order between trade and real GDP may be interchangeable, because trade is also found to have a feedback effect on real GDP (Table 4). The development of trade, according to international economic theory, has an unfavorable effect on unemployment due to search and matching frictions in the labor market and wage bargaining, particularly in the trade involving both homogeneous-product and differentiated-product sectors (Helpman and Itskhoki 2010). Evidence supporting this explanation is shown by the contemporaneous regression results in Table 3, where the coefficient sign for trade is positive. The debate is shown regarding whether capital investment can help to reduce unemployment (e.g., Layard et al. 1991; Rowthorn 1999). Following Rowthorn's theory, unemployment is the result of inadequate capital stock, suggesting a feedback relationship between unemployment and capital investment, as presented by the causality results in Table 4 .

\footnotetext{
${ }^{2}$ Because the VAR model only involves lag variables, determining strong exogeneity is not possible. However, weak exogeneity is deemed sufficient for this paper.
} 


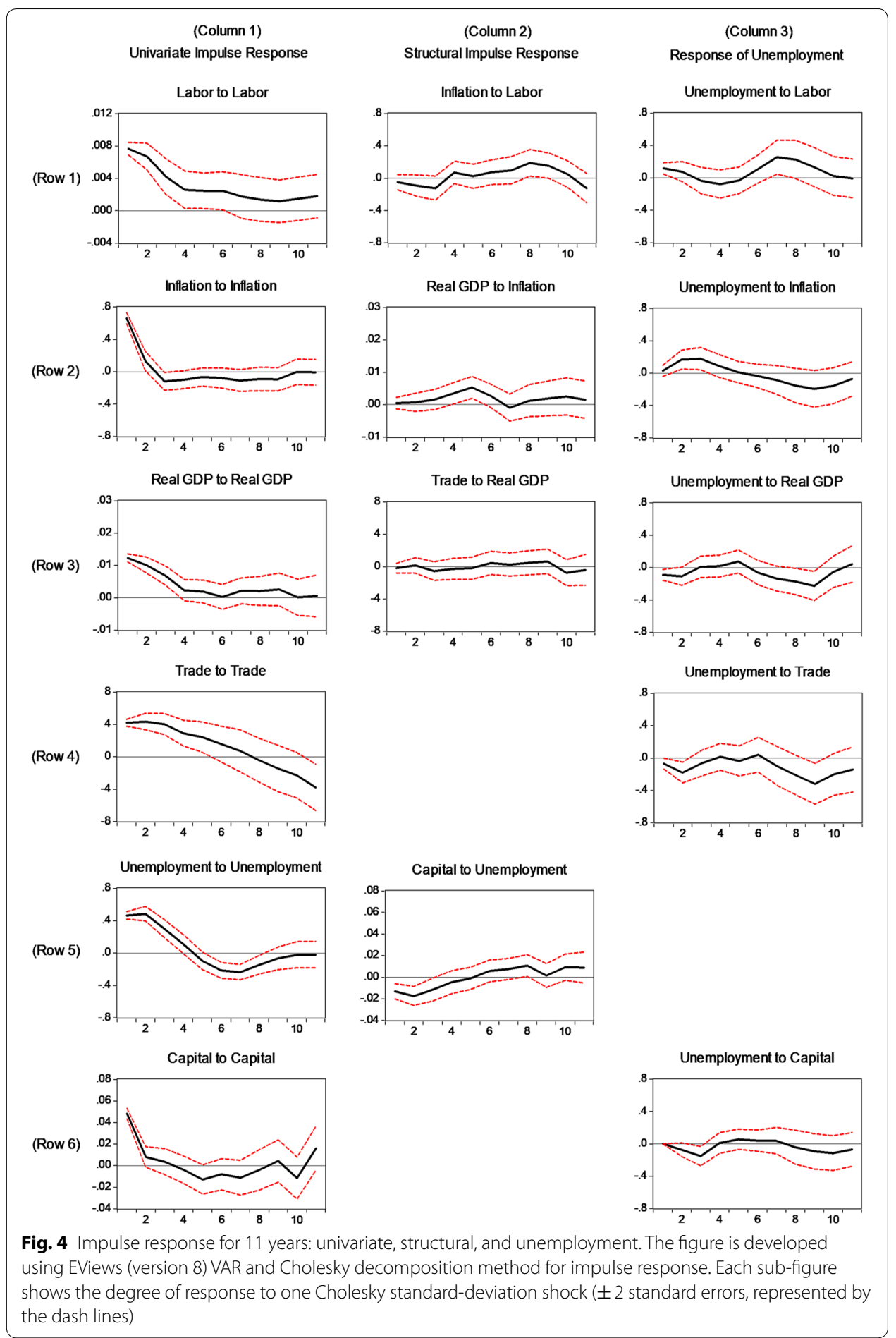

Does the ordering above make sense? First, the exogenous ranking explained above is to provide both empirical and theoretical reasons to form the Cholesky ordering for calculating impulse responses. The Cholesky decomposition is needed, because it calculates the unique shock to each equation, which has similar algorithmic jargon as the Wold causal chain and recursive VAR (Stock and Watson 2001; Wold 1960). 
Figure 4 can be read by row and/or column. Column 1 shows the response of one economic variable to its own innovations. Column 2 shows the impulse response between two variables based on the structural ordering explained above. Column 3 has a focus merely on the response of unemployment to innovations in each of the other five economic variables. This paper uses a different presentation of the impulse response, which is different from the usual format of impulse-response analysis that is arranged in a matrix form, where the diagonal presents the impulse response for the same variable. By row, sub-figures in columns 2 and 3 compare the responses of two variables to the innovations of the variable in column 1: one of the response variables is the variable under this paper's scrutinizing (unemployment). The figure is a closer look at the impulse and response as the lag structure is restricted to be 11 years (same lag length as the VAR model). Nevertheless, patterns in the figure seem to indicate responses of longer than 11 years. Thus, this study increased the timespan of the impulse response to as far as 80 years (Fig. 5). The following discussions refer to both figures interchangeably. The first finding to notice is the univariate pattern of the impulse response (column 1). Except for labor, a shock to each variable reverts to zero for the first time in less than 10 years, consistent with the findings in Table 4 that show labor also to be the most exogenous in the sextuple system. The next step compares responses between two variables (columns 2 and 3) to the innovations of one variable (column 1) by row. In the first row, the response of unemployment to labor shows a stable pattern approximately 18 years later, while the shock to labor gradually fades away for at least 25 years (reverts to zero and becomes stable thereafter), whereas inflation virtually indicates a stable response throughout the predicting period with a slowdown six decades later. ${ }^{3}$ In the second row, a shock to inflation is not shown to slow down for at least six decades later. In this case, responses of unemployment and real GDP take approximately the same length of time before fading away, which is about 38 years. In the third row, responses of unemployment and trade to shock to real GDP are compared. The response of trade to real GDP is consistent with the exogenous ordering in Table 5, which shows no apparent response from trade in the figure. In contrast, unemployment seems to respond slightly more aggressively in the first 10 years only and becomes stable thereafter. The biggest impulse and response are between trade and unemployment, as shown in the fourth row. The shock to trade takes approximately 40 years before fading away, while the response of unemployment is much more aggressive in this case and can take roughly 45 years before the stability of response can happen. In the last two rows, stable responses between unemployment and capital seem to be dominant over time, which is consistent with the weakly significant causality between the two variables (Table 4).

In short, the longest lasting effect of past economic innovations on unemployment is found to be 38-45 years (before becoming stable), with inflation and trade playing the biggest roles. Accordingly, this paper has demonstrated that past economic innovations as far back as 11 years ago have significant causal effects on long-run unemployment. As

\footnotetext{
3 This study's strategy to distinguish between stable and unstable patterns is inspired by Fisher's (1973, p. 499) economic knowledge: "In running an automobile we know that it takes no more petrol on a high plateau than on the lowlands, but that it does take much more petrol when we are going uphill; and, on the other hand, takes less when we are going downhill."
} 


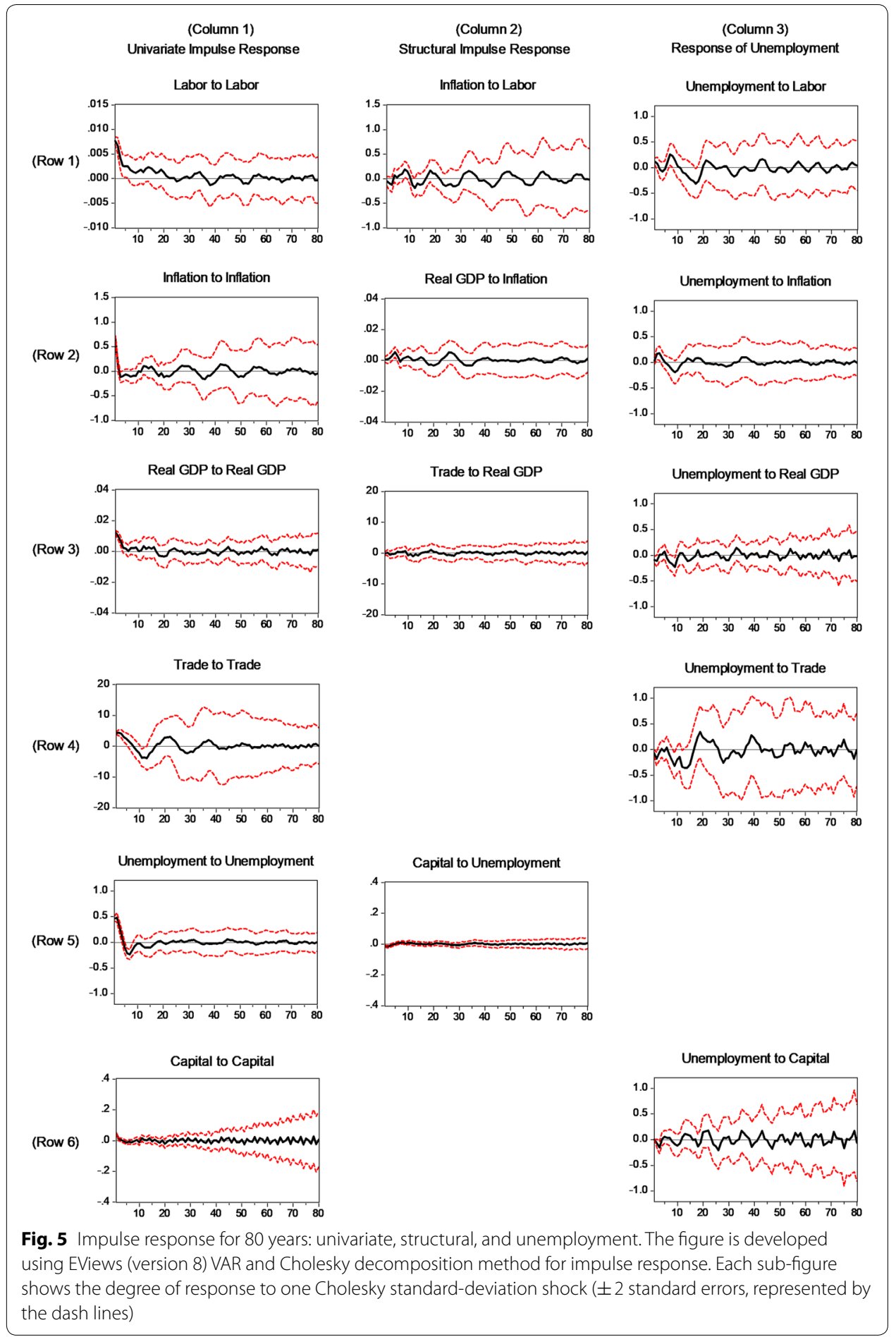

a recap, the selection of 11 years is based on a break in the good performance of unemployment since the year 2000, such performance resumed sometime after the outbreak of the 2008 global financial crisis, details can be found in the theoretical section. 


\section{Conclusion}

The economic inquiry of long-run unemployment that this paper explores is unique in two aspects. First, the long-lasting effects of certain economic innovations in the distant past are conceptualized theoretically with empirical support. The first aspect of exploration corresponds to the second aspect in terms of the effectiveness of the EU economic integration. Specifically, this paper's concern is that the EU policies are for the European level and, therefore, may be unfavorable to employment performance in each member state. In fact, some economic studies (Alesina and Perotti 2004; Alesina et al. 2005; Dabrowski 2010; Svejnar 2002) believe that regional separatism seems to characterize the union more than economic and political integration. In the course of unexpected changes in economic conditions, the past economic experience of individual member states is argued in this study to be a more reliable source of knowledge to follow. Together, long-lasting influences from past economic experience and favoritism toward home economic policies can be barriers to achieving EU economic and political integration. Newly admitted member states to the EU could witness benefits at the EU level, whereas certain economic problems could force some member states to revert to the knowledge of past experience that may not always comply with the union policies. Such policy conflicts or barriers advocate the EU to adopt more policy flexibility for the member states. Brexit is one example in response to the policy nature of the EU, one of which is that being independent of economic policies from the EU is believed to enhance benefits of the free market and free trade in Britain.

Nevertheless, with respect to the policy barriers mentioned above, a policy recommendation for the $\mathrm{EU}$ is to promote cross-cultural entrepreneurship and innovation to revise the structure of comparative advantage among the $28 \mathrm{EU}$ member states, thereby creating new patterns of interindustry and intraindustry trades that could benefit the EU as a whole. The main aim of this policy should be to minimize the unemployment rate in each member state. To promote cross-cultural entrepreneurship, on one hand, the suggestion implies a subset of policies targeting new innovations from cultural diversity within the population of first-generation international immigrants in terms of country-specific experiences, ideas, preferences, and skills. For example, immigrants who share the same linguistic background in multiple EU countries are an advantage for the economies to build business networks; particularly, Guiso et al. (2009) refer to this advantage as a cultural bias in the sense that bilateral trust owing to the same cultural background leads to more trade between two countries. On the other hand, each EU member state should search for new innovations from cultural diversity within the population of immigrants. For instance, by enhancing business platforms for immigrants, that would raise business competition among immigrants, hence encouraging them to innovate based on their country-oforigin creativity and experiences. In particular, Alesina et al. (2016) found evidence of a positive relationship between skill-immigrant diversity and scientific innovation (patenting activities). When innovation is developed from within-country cultural diversity, the subsequent development should be cross-country entrepreneurial networks supplemented by inter-country cultural links among the EU member states. This policy recommendation is in line with the concept of "creative response" proposed by Schumpeter (1947), suggesting that the EU should establish something, 
as Schumpeter articulated "something that is outside of the range of existing practice," that would constructively reshape the subsequent events and long-run outcome rather than a transitional change.

This study's value of originality is evidence on a paradox of unemployment behaviors in relation to other economic conditions, justified with analogical reasoning involving two long-run periods. The paradox proposed by this paper implies that an economy's exposure to changing economic conditions in the distant past can be regarded as a kind of knowledge and learning process, thereby will apply such knowledge to cope with current economic circumstances, such as for reducing the unemployment rate. The role of analogical reasoning in the EU employment performance is shown to be apparent, particularly between the two discontinuous periods distorted for several years by the 2008 financial crisis. This likely indicates that the EU economies had used similar economic reasoning to cope with the upswing in unemployment following the impact of the crisis as before it happened. One important finding of the paradox that is ascertained is that the beneficial influences of past economic experience can help to cope with current unemployment even after a considerable time distance, since the essential economic experience was initially realized. From the empirical results, a considerable time distance is identified to be as far as one decade, while the duration of influence on unemployment is found to be a prolonged period of several decades (depending on the nature of the economic innovations).

This study posits a different perspective from mainstream economic understanding; for example, changes in aggregate demand have only a short-run effect on unemployment, while supply-side policies have long-run unemployment effects. This paper's findings do not reject conventional wisdom of mainstream economic theories, whereas it suggests potential long-lasting influences from past economic experience, as an accumulation of multiple short-run changes (recurrent) and over the long run.

One apparent limitation of this paper is that the study of economic variables is limited to six macroeconomic and international economic events. It is expected that the long-lasting effects of distant past experience found in this paper can be potentially generalized to the impacts of some other economic variables, showing that empirical evidence by future studies is highly desirable.

\footnotetext{
Abbreviations

ACs: Associated Countries; AIC: Akaike information criterion; EMU: Economic and Monetary Union; EU: European Union; GDP: gross domestic product; LM: Lagrange multiplier; SIC: Schwarz information criterion; UK: United Kingdom; US: United States; VAR: vector autoregression.
}

Acknowledgements

The author would like to thank the editors and anonymous reviewers for their time and useful comments.

\section{Authors' contributions}

This paper is single-authored and the research was implemented entirely by the author. The author read and approved the final manuscript.

Funding

Not applicable.

Availability of data and materials

The data analyzed during this study are available from the World Development Indicators database (2019) of the World Bank (https://databank.worldbank.org/data/source/world-development-indicators). 
Received: 1 June 2019 Revised: 19 August 2019 Accepted: 3 September 2019

Published online: 10 September 2019

\section{References}

Abrigo MRM, Love I (2016) Estimation of panel vector autoregression in Stata. Stata J 16:778-804. https://doi. org/10.1177/1536867X1601600314

Alesina A, Perotti R (2004) The European Union: a politically incorrect view. J Econ Perspect 18:27-48. https://doi. org/10.1257/0895330042632780

Alesina A, Spolaore E, Wacziarg R (2005) Trade, growth and the size of countries. Handb Econ Growth 1:1499-1542. https ://doi.org/10.1016/S1574-0684(05)01023-3

Alesina A, Harnoss J, Rapoport H (2016) Birthplace diversity and economic prosperity. J Econ Growth 21:101-138. https:// doi.org/10.1007/s10887-016-9127-6

Andrés J, Doménech R, Molinas C (1996) Macroeconomic performance and convergence in OECD countries. Eur Econ Rev 40:1683-1704. https://doi.org/10.1016/S0014-2921(96)00014-1

Ball LM (2009) Hysteresis in unemployment: old and new evidence. NBER Working Paper No. 14818. https://doi. org/10.3386/w14818

Baltagi BH (2005) Econometric analysis of panel data, 3rd edn. Wiley, New York

Barro RJ, Sala-I-Martin X (1992) Public finance in models of economic growth. Rev Econ Stud 59:645-661. https://doi. org/10.2307/2297991

Baumol WJ (1986) Productivity growth, convergence, and welfare: what the long-run data show. Am Econ Rev 76:1072-1085

Blanchard OJ, Summers LH (1986) Hysteresis and the European unemployment problem. NBER Macroecon Annu 1:15-78. https://doi.org/10.1086/654013

Breitung J (2000) The local power of some unit root tests for panel data. In: Baltagi BH (ed) Advances in econometrics, vol 15. Nonstationary panels, panel cointegration, and dynamic panels. JAI Press, Amsterdam, pp 161-178

Burbidge J, Harrison A (1984) Testing for the effects of oil-price rises using vector autoregressions. Int Econ Rev 25:459484. https://doi.org/10.2307/2526209

Carbonell JG (1983) Learning by analogy: formulating and generalizing plans from past experience. In: Michalski RS, Carbonell JG, Mitchell TM (eds) Machine learning. Symbolic computation. Springer, Berlin

Clark X, Dollar D, Micco A (2004) Port efficiency, maritime transport costs, and bilateral trade. J Dev Econ 75:417-450. https://doi.org/10.1016/j.jdeveco.2004.06.005

Cohen M, Etner J, Jeleva M (2008) Dynamic decision making when risk perception depends on past experience. Theor Decis 64:173-192. https://doi.org/10.1007/s11238-007-9061-3

Dabrowski M (2010) The global financial crisis: lessons for European integration. Econ Syst 34:38-54. https://doi. org/10.1016/j.ecosys.2010.01.002

Daviddi R, Ilzkovitz F (1997) The Eastern enlargement of the European Union: major challenges for macro-economic policies and institutions of Central and East European countries. Eur Econ Rev 41:671-680. https://doi.org/10.1016/ S0014-2921(97)00047-0

Di Tella R, MacCulloch RJ, Oswald AJ (2001) Preferences over inflation and unemployment: evidence from surveys of happiness. Am Econ Rev 91:335-341. https://doi.org/10.1257/aer.91.1.335

Diebold FX (2001) Elements of forecasting, 2nd edn. Ohio, South-Western, p 254

Durlauf SN, Phillips PCB (1988) Trends versus random walks in time series analysis. Econometrica 56:1333-1354. https:// doi.org/10.2307/1913101

Eichengreen B (2012) Economic history and economic policy. J Econ Hist 72:289-307. https://doi.org/10.1017/S0022 050712000034

Fisher I (1926) A statistical relation between unemployment and price changes. Int Lab Rev 13:785-792

Fisher I (1973) I discover the Phillips curve: "A statistical relation between unemployment and price changes". J Polit Econ 81:496-502

Freeman RB, Medoff JL (1982) Substitution between production labor and other inputs in unionized and nonunionized manufacturing. Rev Econ Stat 64:220-233. https://doi.org/10.2307/1924301

Friedman M (1968) The role of monetary policy. Am Econ Rev 58:1-17

Gabor IR (1989) Second economy in state socialism: past experience and future prospects (the case of Hungary). Eur Econ Rev 33:597-604. https://doi.org/10.1016/0014-2921(89)90140-2

Granger CWJ (1969) Investigating causal relations by econometric models and cross-spectral methods. Econometrica 37:424-438

Guiso L, Sapienza P, Zingales L (2009) Cultural biases in economic exchange? Q J Econ 124:1095-1131. https://doi. org/10.1162/qjec.2009.124.3.1095

Gujarati D (2003) Basic econometrics, 4th edn. McGraw Hill Companies, New York

Hausman JA (1978) Specification tests in econometrics. Econometrica 46:1251-1271. https://doi.org/10.2307/1913827

Helpman E, Itskhoki O (2010) Labor market rigidities, trade and unemployment. Rev Econ Stud 77:1100-1137. https://doi. org/10.1111/j.1467-937X.2010.00600.x

Hlouskova J, Wagner M (2006) The performance of panel unit root and stationarity tests: results from a large scale simulation study. Econom Rev 25:85-116. https://doi.org/10.1080/07474930500545504

Hollander JH (1916) Economic theorizing and scientific progress. Am Econ Rev 6:124-139

Holtz-Eakin D, Newey W, Rosen HS (1988) Estimating vector autoregressions with panel data. Econometrica 56:13711395. https://doi.org/10.2307/1913103

Ibarra R, Trupkin DR (2016) Reexamining the relationship between inflation and growth: do institutions matter in developing countries? Econ Model 52:332-351. https://doi.org/10.1016/j.econmod.2015.09.011 
ILOSTAT database (2019) International Labour Organization, Geneva. https://databank.worldbank.org/data/source/world -development-indicators. Accessed 10 Mar 2019

International Financial Statistics and data files (2019) International Monetary Fund, Washington, D.C. https://databank. worldbank.org/data/source/world-development-indicators. Accessed 10 Mar 2019

Ivanov V, Kilian L (2005) A practitioner's guide to lag order selection for VAR impulse response analysis. Stud Nonlin Dyn Econom 9:1558-3708. https://doi.org/10.2202/1558-3708.1219

Kollias C, Paleologou S-M (2006) Fiscal policy in the European Union: tax and spend, spend and tax, fiscal synchronization or institutional separation? J Econ Stud 33:108-120. https://doi.org/10.1108/01443580610666064

Koulakiotis A, Lyroudi K, Papasyriopoulos N (2012) Inflation, GDP and causality for European countries. Int Adv Econ Res 18:53-62. https://doi.org/10.1007/s11294-011-9340-1

Lawless M, Whelan KT (2011) Understanding the dynamics of labor shares and inflation. J Macroecon 33:121-136. https ://doi.org/10.1016/j.jmacro.2010.11.002

Layard R, Nickell S, Jackman R (1991) Unemployment: macroeconomic performance and the labor market. Oxford University Press, Oxford

Levin A, Lin C-F, Chu C-SJ (2002) Unit root tests in panel data: asymptotic and finite-sample properties. J Econom 108:1-24. https://doi.org/10.1016/S0304-4076(01)00098-7

Lucas RE, Rapping LA (1969) Real wages, employment and inflation. J Polit Econ 77:721-754. https://doi. org/10.1086/259559

Neuenkirch M (2013) Monetary policy transmission in vector autoregressions: a new approach using central bank communication. J Bank Finance 37:4278-4285. https://doi.org/10.1016/j.jbankfin.2013.07.044

Nickell S (1981) Biases in dynamic models with fixed effects. Econometrica 49:1417-1426. https://doi.org/10.2307/19114 08

Perkins P, Fedderke J, Luiz J (2005) An analysis of economic infrastructure investment in South Africa. S Afr J Econ 73:211-228. https://doi.org/10.1111/j.1813-6982.2005.00014.x

Phillips AW (1958) The relation between unemployment and the rate of change of money wage rates in the United Kingdom, 1861-1957. Economica 25:283-299. https://doi.org/10.1111/j.1468-0335.1958.tb00003.x

Phillips PCB, Moon HR (2000) Nonstationary panel data analysis: an overview of some recent developments. Econom Rev 19:263-286. https://doi.org/10.1080/07474930008800473

Public Opinion Research Center (1999) Was it worthwhile? The Czechs, Hungarians and poles on the changes of the last decade. Polish Public Opinion. https://www.cbos.pl/EN/publications/public_opinion.php. Accessed May 102019

Rowthorn R (1999) Unemployment, wage bargaining and capital-labor substitution. Camb J Econ 23:413-425. https:// doi.org/10.1093/cje/23.4.413

Saint-Paul G (1992) Fiscal policy in an endogenous growth model. Q J Econ 107:1243-1259. https://doi. org/10.2307/2118387

Schumpeter JA (1947) The creative response in economic history. J Econ Hist 7:149-159. https://doi.org/10.1017/S0022 050700054279

Snowdon B, Vane HR (2005) Modern macroeconomics: its origins, development and current state. Edward Elgar Publishing Limited, Cornwall

Spolaore E, Wacziarg R (2009) The diffusion of development. Q J Econ 124:469-529. https://doi.org/10.1162/ qjec.2009.124.2.469

Spolaore E, Wacziarg R (2013) How deep are the roots of economic development? J Econ Lit 51:325-369. https://doi. org/10.1257/jel.51.2.325

Spolaore E, Wacziarg R (2016) War and relatedness. Rev Econ Stat 98:925-939. https://doi.org/10.1162/REST_a_00554

Stock JH, Watson MW (2001) Vector autoregressions. J Econ Perspect 15:101-115. https://doi.org/10.1257/jep.15.4.101

Svejnar J (2002) Transition economies: performance and challenges. J Econ Perspect 16:3-28. https://doi. org/10.1257/0895330027058

Tversky A, Kahneman D (1991) Loss aversion in riskless choice: a reference-dependent model. Q J Econ 106:1039-1061. https://doi.org/10.2307/2937956

Wold HOA (1960) A generalization of causal chain models (part III of a triptych on causal chain systems). Econometrica 28:443-463. https://doi.org/10.2307/1907733

World Bank national accounts data (2019) The World Bank, Washington, D.C. https://databank.worldbank.org/data/sourc e/world-development-indicators. Accessed 10 Mar 2019

World Development Indicators database (2019) The World Bank, Washington, D.C. https://databank.worldbank.org/data/ source/world-development-indicators. Accessed 10 Mar 2019

\section{Publisher's Note}

Springer Nature remains neutral with regard to jurisdictional claims in published maps and institutional affiliations. 